\title{
ON THE TWO GALICIAS: FROM LESSER POLAND TO THE OUTSKIRTS OF EUROPE, FROM THE ATLANTIC TO THE VISTULA RIVER
}

\author{
ABSTRACT
}

The article is aiming to compare the two European Galicias: the Spanish one, being one of the autonomous communities of Spain, and the historical-cultural region located in the EastCentral part of Europe. Is there, apart from the coincidence of names which may serve as a good starting point for the play of words and anecdotes on 'national characters', something more which links these two distant geographic territories? From the socio-cultural perspective it is worth to have a look at the sphere of social ideas and myths which accompany discussions on the two Galicias. Is there in the complicated and quite elusive (in the sense of uncountable, changing and subjective) matter of local traditions, daily life patterns and customs, any link between the two European Galicias?

In this short article, I will try to refer to certain stereotypes, cultural myths and anecdotes came to being in the sphere of social concepts. They were created, on the one hand, by the media (in particular in the context of the unification of the richer Europe with its poorer part), on the other - by individual human experiences, in whose lives dual Galician adventures entwined.

KAROLINA GOLEMO

Instytut Studiów Międzykulturowych Uniwersytetu Jagiellońskiego.

Key words: Galicia; image; Europe; cultural identity Correspondence: karolina.golemo@uj.edu.pl

This is an Open Access article distributed under the terms of the Creative Commons Attribution 3.0 PL License (creativecommons.org/licenses/by/3.0/pl/), which permits redistribution, commercial and non-commercial, provided that the article is properly cited. (c) The Author(s) 2015.

Publisher: Institute of Slavic Studies PAS [Wydawca: Instytut Slawistyki PAN] 


\section{O DWÓCH GALICJACH: Z MALOPOLSKI NA KRAŃCE EUROPY, ZNAD ATLANTYKU NAD WISLE}

\section{Streszczenie}

Celem tekstu jest próba zestawienia ze sobą dwóch Galicji Europy: hiszpańskiej, funkcjonującej jako jedna ze wspólnot autonomicznych Królestwa Hiszpanii, oraz środkowoeuropejskiej, będącej historyczno-kulturowym regionem, niegdyś częścią imperium Habsburgów. Czy poza zbieżnością nazw, która może być dobrym punktem wyjścia do zabaw słownych i anegdot na temat „charakterów narodowych", istnieje jeszcze coś, co łączy te dwa geograficznie odległe terytoria? Z perspektywy socjologiczno-kulturoznawczej warto się przyjrzeć sferze społecznych wyobrażeń i mitów towarzyszących dyskusjom o dwóch Galicjach. Czy w skomplikowanej i dość nieuchwytnej (w sensie niepoliczalnej, zmiennej, subiektywnej) materii lokalnych tradycji, modelów życia codziennego, obyczajów istnieje jakaś więź między dwoma Galicjami Europy? W tym krótkim tekście postaram się odwołać do pewnych stereotypów, mitów kulturowych i anegdot, które zaistniały w sferze społecznych wyobrażeń. Stworzyły je, z jednej strony, media (zwłaszcza w kontekście jednoczenia się bogatszej Europy z jej biedniejszą częścią), z drugiej zaś przeżycia jednostek, w których losy wplotty się doświadczenia „podwójnie galicyjskie".

Słowa kI u c zowe: Galicja; wizerunek; Europa; tożsamość kulturowa

\section{"GALICIANISM": POLISH AND SPANISH WAY}

$f$ f we were to ask a Pole (not necessarily 'average', as such exist only in stereotypes) where Galicia is located, he would most probably indicate the southeast region of his home country. One more knowledgeable in history would maybe define this territory more precisely, adding that Galicia comprises not only Poland, or Lesser Poland (Pol. Matopolska), but also the territories which currently belong to Ukraine.

If we were to ask a Spanish passerby what Galicia is and where it is located, he would not hesitate to answer that Galicia is a Spanish region (to be more precise one of the autonomic communities of the Kingdom of Spain). Galicia, the north-west outpost of the country, which borders with Portugal and the moody Atlantic waters, commonly associated in stereotypical conceptions to St. James's Way (camino), rainy, windy climate, excellent seafood and sentimental nature of the Galicians. José Ortega y Gasset, when describing individual Spanish regions, wrote: 'Galicia and Lusitania delight in dwelling on the past, basking in their own tears, plunging in romantic sorrows to the sounds of fado and sweet evanescence dispelled in the Atlantic melancholy' (Lewandowski, 2005, p. 258).

The two European Galicias can cause difficulties in terms of linguistic distinctions. The Spaniards managed to resolve this semantic coincidence by introducing the names Galicia and Galizia, respectively. The English, however, kept one name, i.e. Galicia, for both regions and maybe this lies at the heart of various misunderstandings with regard to what Galicia is and where it is located. The Poles call both geographical regions 'Galicja', but the word's derivatives do differ: Polish Galicia used to be populated by 'Galicjanie' and 'Galicjanki', the Spanish one by 'Galisyjczycy' and 'Galisyjki' (although within this use there are inconsistencies as well). By analogy, the adjective 'galicyjski' should refer to the central European context, while 'galisyjski' to the Spanish one. In reality though, the galego language, used in its varieties on the territory of the Spanish Galicia is denoted in 
Polish both as 'galicyjski' and 'galisyjski'. This terminological similarity is therefore unavoidable.

It could be assumed that in practice few Spaniards realize that in the distant central Europe there lies another Galicia, which until recently was separated from the rest of Europe by the so-called iron curtain. One of my colleagues - a professor from the University of Seville, who came to Cracow in 2012 for an academic exchange, was surprised and amused to hear that he had flown to Poland to find himself in... Galicia. This Andalusian from the southern outskirts of Spain, acquainted with the world and well travelled, was nevertheless surprised by such turn of things. He experienced an unexpected confusion of cultural concepts. While a Spanish friend of mine, a globetrotter native of the Galician city A Coruña not only was not surprised in the slightest by the existence of the two Galicias, but he was the one to surprise me with his comment, when, during a conversation, I confessed that I, indeed, also came from Galicia, he calmly asserted: 'In fact, I have always thought there is something Galician about you'. Where does this opinion stem from? What is it based on?

Is there, apart from the coincidence of names 'Galicja, 'Galicia', 'Galitzia', 'Galiza', 'Galitsia'1, which may serve as a good starting point for the play of words and anecdotes on 'national characters', something more which links these two distant geographic territories? I am not going to undertake here in-depth historical, political and economic analyses, as I am aware that a thorough research and comparison of the two regions would require a multilateral, professional preparation. Doubtless, it would be tempting to compare, for instance, the links of the Spanish Galicia with Portugal and - on the other hand - the relationship of Ukrainian and Polish territories which form the central European Galicia. I leave this topic to historians specialised in the field. From the socio-cultural perspective it is worth to have a look at the sphere of social ideas and myths which accompany discussions on the two Galicias. Is there in the complicated and quite elusive (in the sense of uncountable, changing and subjective) matter of local traditions, daily life patterns and customs, any link between the two European Galicias?

In this short article I will try to refer to certain stereotypes, cultural myths and anecdotes came to being in the sphere of social concepts. They were created, on one hand, by the media (in particular in the context of the unification of the richer Europe with its poorer part), on the other - by individual human experiences, in whose lives dual Galician adventures entwined.

\section{DANUTA HÜBNER, JOSEPH ROTH, JOHN PAUL / - GALICIAN PRESS ON POLISH GALICIA}

Intrigued by the links between the Atlantic Galicia and the Polish one, I decided to check whether in the local Galician press there are any references to the 'sister' region on the other side of Europe. While searching through the Internet archives of the daily paper $L a$ voz de Galicia (The voice of Galicia) with 'Galitzia' as the key word typed in the search engine (i.e. the name used by the Spaniards to distinguish their own Galicia from the central European one), I found 54 press articles in which this term appeared. ${ }^{2}$ In some of

\footnotetext{
1 These last two names denote the Spanish and the Polish Galicia, respectively, in the galego (Galician) language.

2 Internet research in the newspaper's archives of 1 September 2012. All quotations from Castilian and Galician in my own translation.
} 
them, on the Polish Galicia there was only a brief explanatory note aimed at emphasizing that the author intended to refer to the region in the other part of Europe with the same name. Usually it was clarified with reference to individuals native of the region of the present south-east Poland, to stress that someone originated from 'the other' Galicia. It was the case of Joseph Roth, on whom one of the articles read, when presenting his biography: ' $[. .$.$] he originated from the other Galicia - the Austro-Hungarian one, subse-$ quently Polish and then Soviet and nowadays Ukrainian' (Molina, 2002). When in 2012 he was awarded the Prince of Asturias Award in literature, his Polish Galician origins were also brought to attention during the congratulation speech: 'he originated from a Polish Jewish family and ended up in Asturia' (Casal, 2012).

When in 2004 Danuta Hübner took the office of the Commissioner for Regional Policy in the European Union, Galician press tried to cast some light on her. Of course references to the origins of the Polish minister were unavoidable: We can say that Danuta Hübner is a Galician [the journalist wrote literally gallega, i.e. a Galician from the Spanish Galicia - K. G]. Or almost, as she was born in the historical Galicia, a region re-baptized on the modern Polish map [sic!] as Podkarpacie. (Sampedro, 2004).

And if Hübner is to coordinate the allocation of structural funds for regional development and in addition she originates from Galicia, how one is not to be tempted to compare the economic situation of the Polish Galicia to the Atlantic one? A correspondent from Brussels wrote then:

[...] Nisko, Hübner's native town of 16 thousand inhabitants is unfortunate to find itself in the poorest EU's region, where, according to Eurostat the income pro capita equals $30 \%$ of the European average, i.e. 6,900 euros per annum per person. To put it in perspective, a Spanish Galician earns on average 15,500 euro per year.

\section{And so goes a prognosis:}

If within the next two decades Poland receives financial help in the amount equal to what Spain had received, not even St. Kazimierz, the patron of Polish people, will recognise Nisko, Kraków and Katowice (Sampedro, 2004).

On Danuta Hübner, as a Commissioner for Regional Policy in the EU, journalists wrote also that she was responsible for negotiating for the Spanish Galicia the construction of a fast rail connection, AVE, which would link the northern Portugal (Porto) with the south of Galicia (Vigo). The authors stressed that the negotiations with regard to the Spanish Galicia were conducted by a Polish commissioner, also originally from Galicia, but a different one: 'Ms Hübner, a Polish Galician, held talks with the president of the Atlantic Galicia and announced that she would back the fast rail project' (Alcalá, 2006), a good example of Galician solidarity in the European family. In June 2006 news appeared about an 'eco' visit by Hübner in the Spanish Galicia and her meeting with the representatives of Xunta, the local governmental authorities. And on this occasion the journalist did not fail to mention the origins of the European commissioner either: 'Danuta Hübner, native of the Polish Galicia, encouraged Xunta to take care of the ecological aspect of the region: 'Galicia has to protect its natural environment, because it represents its treasure'3 ("Europa y el 'mito de la Galizia verde'", 2006).

3 One of the articles entitled 'Viva the poverty' was instead critical towards the Polish Commissioner. It said that she did not care about improving the situation of poor Spanish Galicia: 'although she knows the impoverished Galicia from her native Poland, in a cunning way she introduced poverty tackling as a main tool of [economic] development. See Barreiro Rivas (2005). 
In April 2005, after the death of the Polish Pope, the daily paper La voz de Galicia, published an article in which Galician bishops recalled a particular John Paul II's fondness and attachment to the Spanish Galician soil. Karol Wojtyła, also native from Galicia, remained imprinted in the memory of the Galician clergy and its Catholics as a pope blessed with a sense of humour. One of the clergy men said that the Polish Pope used to joke on the close similarity between the two Galicias (Loureiro, 2005).

\section{THE OTHER GALICIA: A POORER SISTER IN THE EUROPEAN FAMILY}

Before Poland joined the structures of the European Union, Galician newspapers had published a few articles on the 'other', poorer, Polish Galicia aspiring to be accepted in the European Union. Articles on this matter in the daily paper La voz de Galicia appeared in a section bearing an impromptu name 'El finisterre polaco'4. The name referred to Finisterre (Spanish Fisterra), a district in the A Coruña province, located indeed in the Spanish Galicia. The most popular part of this small district lies on Cape Finisterre, the westernmost point of the continental Spain. The etymology of the word refers of course to the Latin expression finis terrae - 'land's end'. It is on this Cape, according to the then-knowledge of the habitants of the Iberian Peninsula, that the Old World finished, until during the colonial conquest the New World was discovered. The use of Finisterre in relation to news from the south of Poland was not only a witty play of meanings, but also clearly showed the ideas and knowledge about the other Galicia (upon Vistula river, that is where 'land ends'?) which the Spanish public could hold under the influence of the local press. Later in this publication I will refer to a few press articles from the period prior to the accession of Poland to the EU, while bearing in mind that this is not a representative image of 'our' Galicia, but simply an attempt to display certain mental patterns on concrete examples. ${ }^{5}$

The authors of the articles in La voz de Galicia, when writing about Poland as a candidate to the accession to the EU, usually entwined in their message at least a mention about Galicia, a southern region of the country on the Vistula. Despite the fact that Polish Galicia does not constitute an official administrative term, Spanish (or to be more precise Galician) journalists were clearly trying to illustrate this astonishing terminological coincidence to their readers and often ventured to make (not always well-founded) socioeconomic comparisons between the two Galicias. In an article on Polish dairy industry the author wrote: 'The best prepared farmers are organized in cooperatives, while corporations such as Danone or Nestle buy milk in regions like Galicia [es. Galitzia] or Silesia 20 per cent cheaper than in its Atlantic sister region (Sampedro, 2002b). Two years ahead of the accession to the EU by Poland a Galician daily newspaper wrote also on the young Poles from the 'other Galicia':

Polish Galicia, who soon intends to join the EU, is a region of 5.4 million inhabitants, i.e. double the population of the Spanish Galicia. However, the number of young people exceeds

4 I am referring here to the aforesaid 54 texts selected from the newspaper's archives.

5 I would like to thank my Spanish Galician colleague, Dr Francisco Seoane Pérez, researcher at University of Castile-La Mancha, who helped me to reach the archives of the daily paper La Voz de Galicia in A Coruña. Without his involvement and sympathy for my project related to the 'two Galicias', it would have been more difficult to gather the material of my interest, both the press and the anecdotal one which exist in the memories and unwritten popular tradition. 
threefold that of our region. Moreover, they are much better educated and prepared. ${ }^{6}$ What is the problem then? Mostly unemployment [...] (Sampedro, 2002a).

The author explains that the unemployment among the young Poles in Malopolska (located, according to the paper, in the 'western Galicia') reaches 31\%, while in the 'more eastern part of Galicia, called Podkarpacie' in 2000 it was nearly $60 \%$. The subsequent part of the article features further comparisons between the two European Galicias: 'in Polish Galicia young people under the age of 15 make up $21.4 \%$ of the total population whereas in 'our Galicia' - only 13\%. The paper quotes statements of young Poles, describes their rich educational profiles, excellent command of languages and incredibly low earnings: 250-300 euro per month. Journalists prognosticate on the accession of Poland to the EU and again recourse to Galician comparisons:

For those competent young people, the enlargement [of the EU] and free movement of people will bring a plethora of possibilities. Already now thousands of Poles decide to live and work in the entire Western Europe. They are much more competitive [in other words: they earn significantly less] than Galician bricklayers in Cologne or Moroccan strawberry pickers in Huelva (Sampedro, 2002a).

In another text we find a comment on the fact that at the turn of the $21^{\text {st }}$ century Spanish Galicia doubled its exports to Poland ("Galicia duplicó el último año sus exportaciones a Polonia", 2002). In addition, in 2002 the Spanish Consulate in Poland registered only four Galician residents in Poland, but the situation, according to the paper's correspondent in Cracow may soon change.

The accession of Poland to the EU was linked in the Galician press with the enlargement of the markets. And again the two Galicias were compared. Journalists were making prognoses that the relationship between Poland and Spanish Galicia would tighten enough so that it would cease to be a mere coincidence of the two European regions' names, and Sofia Casanova would no longer be the only symbolic link between the two regions? ("Galicia duplicó el último año sus exportaciones a Polonia," 2002). Perhaps the most meaningful article aimed at presenting the EU candidate and drawing comparisons with Spanish Galicia ahead of Poland's accession to the EU was a text entitled La 'Galicia' más pobre del continente llama a las puertas de la Unión Europea (2002, The poorest Galicia on the continent knocks on the European Union's doors). It stated that the two European Galicias were often mistaken and, when compared, as many similarities as differences emerged. First of all, however, Galicia and Galitzia do not know each other. For this reason La voz de Galicia published a few observations with the aim to present this distant region in the East-Central Europe to Spanish Galicians. Polish Galicians, similarly to the inhabitants of the Galician Rianxo, worship the Black Madonna (veneran a una virgen moreniña), but from Częstochowa. The cuisine of the population of both Galicias consists mainly of pork and beef (its produce constitutes also the main element of the local meat farming business). Both Polish and Spanish Galicians appreciate good varieties of potatoes. Among other similarities between the regions are, according to the author, attachment to the land and farming traditions (he explains that Poland managed to keep pri-

\section{-....}

6 Statistics related to education levels are significantly in favour of Polish Galicians (galitzianos) in comparison to their Spanish counterparts (gallegos). The educational data for Spanish Galicia are the following: primary education $67 \%$, secondary 14\%, higher 19\%. For Polish Galicia the equivalents are $15 \%, 73 \%$ and $12 \%$, respectively (Sampedro, 2002b).

7 The figure of Sofia Casanova will be discussed further in the text. 
vate land ownership even during the communist period), religiosity and a history marked by emigration. As for the differences, the Galician journalist writes:

Spanish Galicia's wealth is double that of its Polish relative. Two of the regions which are part of Galicia (Małopolska and Podkarpacie) will find themselves among the dozen poorest regions of the EU the moment the accession comes. Galicia will instead take the $60^{\text {th }}$ place in this ranking. [the poverty ranking - K. G.]. ("La 'Galicia' más pobre del continente llama a las puertas de la Unión Europea", 2002).

Finally, the Galician reader is informed that in 'his native' Galicia people earn $65 \%$ of the European average pay while in the other Galicia only $30 \%$ (Ibid.). ${ }^{8}$ Talking about a median income per capita, one needs to quote an ironic, although well-made comment by Lois Blanco: the accession of new countries to the EU, including Poland, will mean that the Galician considered until this day as poor will become richer 'as a result of a perverse statistic dependency' (Blanco, 2004). Since the Union will be joined by poorer countries, which will lower the general economic level of the EU, Galicians' pay will automatically jump from 68 to $73 \%$ of the European average' (Blanco, 2004). The journalist warns against negative consequences of the EU's enlargement for the Spanish Galicia and quotes a triple 'red light'. Firstly 'the amount of soup will stay the same, but there will be many more diners' hence each Galician will receive a smaller food portion per capita. In other words, the flow of the European funds will change direction: from the poor Galicia to the even poorer Galitzia. Secondly, Polish Galicia will dominate the Spanish one since it will compete by use of its cheap work force and central location on the continent and therefore attract more investment. And no increased export to the new EU Member States will compensate this loss. The third 'red light' results from the fact that the Galicia's regional governmental authorities engage only, according to the author, in debates on the economic status. We could further add to the words of the journalist that: it will deal with internal matters instead of elaborating a strategy to outsmart the new, poorer relative with a similar name, but better perspectives in the European family (Blanco, 2004).

\section{FROM THE ATLANTIC TO THE VISTULA: THE CASE OF SOFIA CASANOVA LUTOSLAWSKA}

I found traces of what could be defined as 'dual galicianism' in press articles (not only those from the already quoted La voz de Galicia) as well as other publications. I have mentioned earlier famous people from central Europe who were portrayed in the local Spanish Galician newspapers as characters 'native of Galicia'. Apart from those widely recognized, it is worth mentioning some other, less known figures who have somehow acted in their own way as links between the two Galicias.

8 The newspaper published also several other articles (both in Spanish and Galician) aimed at presenting 'the other Galicia' prior to its accession to the EU. The latter was described, for example, as an area 'erased' from the map, 'a huge region which had lost its name'. Journalists explained that Galicia used to be a vast area of 90 thousand $\mathrm{km}^{2}$ in the Central Europe and that perhaps because of its size continues to be more recognizable than the Spanish Galicia, although it ceased to exist officially. Also cited was Cracow as a former capital; an economic situation 'much more disadvantageous than the one in [Spanish] Galicia; and John Paul II, who was native of Galicia. See "Unha enorme rexión que perdeu o seu nombre" (2004); “Una tierra borrada del mapa que ha perdido hasta su antiguo nombre" (2002). 
We need to start from a singular figure who could serve as a prototype of the dual galicianism, Sofia Casanova, a Galician born in 1861 in Almeiras, not far from A Coruña. Sofia Pérez Eguia y Casanova is her full surname. A poet, author and journalist, she earned her place in the Spanish history as a first woman war correspondent (Dopico, 2011). Considered by some, who stress her courage, strength, independence and commitment to the women's emancipation, as one of the first feminists and interpret her legacy according to the currently popular gender key. ${ }^{9}$ She met her future husband, Wincent Lutostawski, then a philosophy student with aristocratic origins, in Madrid, where he came to research the sources of the European pessimism in Spanish poetry (Dopico, 2011). Maria Filipowicz-Rudek, Casanova's biographer and expert in her legacy, calls her a 'Polish-Spanish writer' (which emphasizes her links to both territories) or, more poetically, 'the princess of Polish snows' (Filipowicz-Rudek, 2003, p. 167).

Sofia Casanova was a subject of quite a number of publications (mostly, but not exclusively, undertaken by initiative of Spanish authors $\left.{ }^{10}\right)$. She was even nominated to the Nobel Prize in Literature. Nonetheless, according to Marcos Gallego, author of the documentary ${ }^{11}$ about the writer, 'despite her involvement in the European culture and journalism in the first half of the $20^{\text {th }}$ century, today Sofia Casanova remains unknown not only in Spain and the Spanish Galicia, but also in Poland'. ${ }^{12}$ On the occasion of a recent $50^{\text {th }}$ anniversary of birth of this 'Spaniard by heart, Pole by choice', the Nature Museum in Drozdowo organized an international conference. ${ }^{13}$ The same occasion was marked by 'Wysokie Obcasy'14 with a vast article presenting the figure of Sofia Casanova Lutosławska, interleaved with the writer's, her husband's, daughters' and relatives' memoires (Szostak, 2011). Casanova did not have an easy life both because of the turbulent times she lived in (she outlived two wars and heavy years of communism in Poland), and a complicated family and personal situation. Her husband, a respected philosopher, was said to write before their wedding in one of his diaries: 'the presence of a woman in a life dedicated to the pursuit of knowledge seemed to me a serious obstacle' (Szostak, 2011) From the relations of biographers and researches of their lives we can draw a conclusion that their relationship cost Sofia plenty of sacrifice. On hearing the news about the Polish-Spanish wedding both families were reportedly terrified. Lutosławski's father considered his marriage with a foreigner a folly. He was afraid that she would not want to stay in Poland. Sofia's relatives, with the help of a friend ambassador, tried to gain some intelligence in order to find out who this 'barbarian from the North' was (Szostak, 2011). It may sound funny, considering the geographical location of the Atlantic Galicia with respect to the rest of Spain. Lutosławski, the 'apologist of Polish messianism'15 with depressive tendencies,

\section{- • • •}

9 See Filipowicz-Rudek (2003, pp. 167-171); Hooper (2008, 2010, pp. 61-78).

10 A prominent expert in Sofía Casanova's life is a Spanish Galician $M^{a}$ Rosario Martínez, author of a noted biography of the writer, see Martínez (1999).

11 The document A maleta de Sofía (Sofia's suitcase) presents the life of Casanova-Lutosławska against the backdrop of turbulent events of the $20^{\text {th }}$ century. The title makes reference to a suitcase in which Sofia kept her notes, her novel manuscripts, souvenirs and photographs which got lost during the World War II. See the trailer from the homonymous film at: http://www.youtube.com/watch?v=VzOgpfq_j7A (10.09.2012).

12 See the Conversation with the Spanish director Marcos Gallego about his film about the Polish journalist Sofia Casanova-Lutostawska, (in Polish): Truszczyński \& Gallego (n.d.).

13 A conference entitled "Sofía Casanova Lutosławska - hiszpańska pisarka, Polka z wyboru" (Sofia Casanova, a Spanish writer, a Pole by choice) took place in September 2011 in Drozdowo, in the former country home of the Lutosławski family. On the occasion of this event Sofia's book Wiecej niż mitość (More than Love) translated by her daughters was promoted. Information on the conference can be found on the website of the Drozdów Nature Museum: http://www.muzeum-drozdowo.pl (7.09.2012).

14 Literally High Heels, a weekly insert to the daily newspaper Gazeta Wyborcza which covers current sociocultural topics.

15 The term is taken from the description of the book Więcej niż mitość published by Drozdowo Nature Museum. 
lost in his scientific divagations, visions of the home country's liberation and religious ecstasy, was expecting from his life companion, above other things, a son since a descendant of a foreigner, according to the visions of Adam Mickiewicz's Piotr from "Dziady"16 (whom Lutosławski drew his inspirations from) was to become a national hero ${ }^{17}$. Instead his Galician wife gave him four daughters, thus not helping to fulfill the prophecy. ${ }^{18}$ When she succumbed to tuberculosis, the Pole left her and married a young Polish girl in the hope that maybe she would give him the desired male offspring. The Atlantic Galician felt so at home in her new country that she decided to stay here nevertheless after her separation from her husband. Sofia Casanova acted as an inter-cultural link not only between the two European Galicias, but between Poland and Spain in general. At the beginning of the $20^{\text {th }}$ century, during her stay in Madrid, she propagated Polish independency aspirations and opposed Polish progressivity in matters of sex equality to the conservative Spain. She wrote: 'In Poland there are countless female doctors, pharmacists, botanists, agronomists and authors who reached an independent status' (Szostak, 2011) Her apartment in Cracow in Na Groblach Square was visited by foreigners and Poles. Among frequent visitors were Władysław Reymont, Stanisław Wyspiański and Jan Kasprowicz while Roman Dmowski was a regular diner. Casanova, a polyglot (she supposedly spoke eight languages), frequently wrote about Poland and Eastern Europe to Spanish newspapers: La Época, El Liberal, El Mundo, Galicia ("Os cadernos perdidos de Sofía Casanova," 2011). Her articles were published in the New York Times or Gazeta Polska. Up to 1936 she was a resident correspondent of the Spanish daily newspaper $A B C$. During the First World War she was active in the Polish Red Cross. Initially she believed in the Russian revolution, admired women's manifestations and their fight for equality. She interviewed Lew Trocki. Soon after, having known the dark side of the new system, she expressed an opinion that 'the Soviets are one of the most barbarian forces in Europe' (Szostak, 2011). During the Spanish Civil War she supported Franco. She kept the General's photo with a personal dedication as a souvenir.

The three daughters (Maria, Isabelle and Halina, called à l'espagnol Manita, Belita and Halita) gave her 13 grandchildren. The latter called her 'babunita', i.e. a mix of a Polish word 'babunia' (granny) with a Spanish diminutive ending. One of Casanova's grandchildren is Father Karol Meissner, a monk in the Benedictines monastery in Tyniec near Cracow (Szostak, 2011).

\section{FURTHER INSTANCES OF DOUBLE GALICIANISM}

On the occasion of the Prince of Asturia Prize award in 2011 there was a 'dual Galician' accent, not only because of the already mentioned Joseph Roth, the literary award laureate. The Renacer Association, which helps homeless people, was also honoured for social work. Among the laureates was Jerzy (presented in the newspaper as Jertzy), a Pole from Cracow who has lived in the Spanish Galicia for the last 17 years. When handed in the award he reportedly said: 'I am a dual Galician since I was born in Galicia, the Cracow

16 Literally Forefathers' Eve, a drama in four parts written in the $19^{\text {th }}$ century by Adam Mickiewicz.

17 In Polish: "Wskrzesiciel narodu / Z matki obcej; krew jego dawne bohatery, / A imię jego będzie czterdzieści i cztery" (A. Mickiewicz, Dziady Część III).

18 One of them died at the age of five. Lutosławski allegedly refused to call a doctor arguing that he was able to heal her with his energy (See Szostak, 2011). 
one'. According to the local press, the voluntary's comment made the Prince of Asturia smile ("Premio de príncipes para Renacer", 2011).

Gosia Trebacz, a Polish artist who has lived in the Spanish Galicia for several years, considers herself a 'double Galician' as well. On the occasion of one of her exhibitions La voz de Galicia published an article depicting the figure of the Cracow-born artist. Trebacz came to Madrid in the 1990' to study art. There she met her future husband, an architect. After a short while they moved for professional reasons near the city of A Coruña. Raised in Madrid, her husband apparently joked about her saying that she 'is more Galician than the Galicians themselves. ${ }^{\prime 19}$ (" 'Mis niños tienen aquí una calidad de vida maravillosa'", 2007) Trebacz says that she likes the character of the local people: although reserved at first, they are honest and can be true friends. She gets along well with them. The artist announces in the article that she is planning to stay in Galicia and defines her children as 'galleguitos', i.e. little Galicians. Gosia Trebacz's experiences were compared on the portal laopinioncoruna.es, with Sofia Casanova Lutosławska's biography:

Gosia Trebacz took an inverse route to the A Coruña writer Sofia Casanova, who abandoned Spanish Galicia to live in the Polish one. Gosia Trebacz, similarly to Sofia Casanova, took roots in the new location to which love brought her. One left Kraków for A Coruña, the other swapped A Coruña (ciudad coruñesa) for the former Polish capital. The parallels between the two women go as far as to their character traits such as fortitude and resistance in front of obstacles.

At the end of this interesting juxtaposition of the two 'double Galicians' the author of the article specifies: 'while Sofia Casanova staked her card on writing, Gosia Trebacz preferred painting brushes' (Bugallal, 2008). The latter talks about herself towards the end of the text: 'I am a dual Galician, a Polish and a Spanish one [gallega polaca y gallega española]. Polish Galicia is very similar to this one: although there is no sea, the landscape is the same' (Bugallal, 2008). The article was commented by one of the portal's female readers who suggested that Trebacz's paintings could be a good starting point for fraternisation of both Galicias so that they become partner regions. She further observed that Gosia's works are often depressive and lack the light. Perhaps that is why they fit so well in the gallego character. The latter, however, according to the reader, do not correspond in the slightest to the open and sentimental nature of Polish and Ukrainian Galicians, whom she had the chance to meet, nota bene, in the Spanish south, in Valencia.

When talking about transnational Galician links and crossovers from one Galicia to the other, it is worth mentioning also Tamara Lorenzo, a pianist native of the Spanish district of Ortigueira. Thanks to a scholarship of a local foundation she ended up studying in Cracow. Betriz Antón writes about her in an article saying that, although Cracow's mediaeval streets do not resemble at all the rural character of her native land, nor the sea fog which wraps Cape Ortegal 'has much to do with the polar cold which holds the Polish city in its embrace in winter', Lorenzo found here her second home (Antón, 2008). A Galician from Spain, scholar of Prof Andrzej Pikuła, founded in Cracow Galicia Pianist Association. ${ }^{20}$ Tamara Lorenzo confesses that she loves music from her native Galicia and tries to promote it in Cracow so that its Galician residents get the chance to know it as well. She adds that the artistic output of Marcial del Adalid is clearly inspired by Frédéric Chopin (who, as commonly known, did not originate from Galicia, but is treated as a symbol of

19 Literally "más gallega que los gallegos".

20 See Cultura Galega (n.d.). 
the Polish identity in general). In a sense Sonia Lebedynski is also a dual Galician. She lives in the A Coruña province Comarca of Barbanza), she speaks Galician, but her surname reveals her Polish or, more precisely, Galician roots. Her great grandfather, a Pole from Galicia, wanted to emigrate to Buenos Aires, but the fortune made that the ship on which he was travelling, crashed near the shores of the other Galicia - the Atlantic one. Sonia's ancestor settled then on this land and founded a big family. 'I am Galician, a descendant of a Pole from Galicia' - reminds the singer' (Piñeiro, 2010).

\section{GALICIA AND HER DOUBLE IN THE NEW WORLD}

Since we are talking about overseas migrations from both Galicias to Argentine, it is worth quoting a recently published article by Edouard Pogoriles from the Argentine daily newspaper 'Clarín' meaningfully entitled Galicia y su doble (Galicia and its double) (Pogoriles, 2012). The author presents therein the two European Galicias: the first, the Spanish one, with its unforgettable cities of Vigo, Orense, La Coruña, Santiago de Compostela and the beauty of landscape. He mentions that, once isolated from the rest of the continent due to its landform features, today the area combines modernity and tradition: on one hand there are motorways and fast rail, on the other - romantic maritime ports, centenary churches and local legends. Galicians' migrations to America are remembered by street names in the city of A Coruña of agglomerations of emigrants: Havana and Buenos Aires. These cities are until today associated by Galicians with freedom since it is indeed where, on the other side of the ocean, Galician culture and language were cultivated while being discriminated in Spain during General Franco's regime. In the Argentinean and the Cuban capitals books in Galician language were published and the Galician anthem could be heard, banned on the Spanish soil by Francoist government.

On the other Galicia, Pogoriles writes that it does not exist on European maps, but it did in the period between 1772 and 1918, as a part of the Austro-Hungarian Empire. He cites the sister cities, Cracow and Lviv, where many languages were spoken and which bring associations to Florence. It is from this Italian city, reminds the journalist, that Polish

elites brought 'their princesses and their architects' (Pogoriles, 2012). Pogoriles, quoting Stanislaw Lem, presents Galicia of that period as an area multicultural par excellence. He writes about Galicians, by repeating Solaris's author words they were truly European citizens, that back then 'even dustmen spoke four languages'. Some elderly Galicia's citizens owned four passports at the same time: Austrian, Polish, Russian and Ukrainian continues the journalist. And he assures the readers that, although Galicia 'survived only on $19^{\text {th }}$ century maps, photographs, old tourist guides and centenary buildings', an attentive ear can still catch the 'song of those who passed away' (Pogoriles, 2012). The most interesting aspect of the article is the comparison of the two Galicias from the period of mass migration across the ocean. The habitants of the former were leaving from the ports of A Coruña and Vigo with the shipment company Transatlántica Española, while those of the latter, from Austro-Hungarian Galicia started their journeys at the port of Trieste or Fiume (Rijeka) on the ships owned by the sea company Unione Austriaca di Navigazione (called the Austro-American) or left from Germany on ships owned by Hamburg Amerika Lines (Pogoriles, 2012). It turns out that the dream about a better life is yet another element which Spanish Galicians shared with the Polish ones. 
Experts in Polish Galicia are more inclined to the opinion that the coincidence of the two names is accidental and, to support this view, point out to the different etymology of the two terms: the Spanish Galicia originate from the name of its habitants, Gauls (Celts from Gaul), while that of the Polish region from the Kingdom of Galicia-Volhynia (Pol. Księstwo Halickie) ${ }^{21}$ (Filipowicz-Rudek, 2012, p. 10). The coincidence of the names (independently of the fact whether accidental or not) can (and often does) give rise to semantic chaos. In a number of texts from La Voz de Galicia the authors mention the misunderstandings which result from this similarity.

In November 2002 an oil tanker 'Prestige' sunk not far from the shores of Galicia while transporting approximately 70 thousand tons of oil. The leakage to the sea caused unimaginable damages to the ecosystem. It was one of the biggest ecological catastrophes ever occurred in Spain. The contaminated sea between the city of A Coruña and Cape Finisterre was then named 'the Death Coast'. A couple of days after the tragedy Ignacio Ramonet wrote about this incident: 'Probably never before Galicia had been so commonly talked about as because of this tragedy' (Ramonet, 2002). Information from the region made headlines of almost all television news programmes worldwide. Ramonet commented on this occasion that in many parts of the globe the word 'Galicia' was heard for the first time. Footage of the oil tanker sinking contained unavoidable misunderstandings. 'Not to look far away - remembers the author of the text - many French journalists were not reporting about Galice, although this is the right term to refer in French to Spanish Galicia, but about Galicie (Galitzia), i.e. the Polish region with almost identical name' (Ramonet, 2002). The similarity of names which results in misunderstandings and inaccuracies was brought up also in other texts. Some Galician friends of mine reckon (and I believe rightly so) that in the Anglo-Saxon literature the term 'Galicia' much more often denotes the Polish-Ukrainian rather than the Spanish Galicia.

La voz de Galicia published an article with an interview, from which one can draw a conclusion that native Galicians from time to time have to fight for their distinctive character not only from Spain, but in a sense from 'the other', central European Galicia. Professor Victor Freixanes, author and editor of the publication entitled Galicia. Unha luz no Atlántico (lit. Galicia. A light over the Atlantic, 2001) dedicated to the Galician identity, explains the circumstances surrounding the writing of the book. ${ }^{22}$ (Freixanes, 2001). A few years before it was published, he had visited various book fairs abroad with a friend and when they mentioned Galicia, it was first associated with the Polish region (Galitzia polaca). It was only following an explanation that they in fact had meant Spain, their interlocutors associated it with Santiago de Compostela. Freixanes wanted therefore to write a book on the Spanish Galicia which would identify this region not only with the attractive pilgrim's route Camino de Santiago (Ramírez, 2002). Several years later the same Victor Freixanes expressed in La voz de Galicia a similar opinion with reference to the lack of knowledge on the Spanish Galicia in the world, whose fragment I report below:

21 There are, however, other interpretations of this name coincidence, referring to the Roman etymology of the term 'Galicia' (the land of Gauls), also in the case of 'our Galicia'. This hypothesis is supposedly backed up by the name of the river San (which in Gaul's language meant indeed 'river'). On Celtic toponymic names and rivers in the proximity of Krakow see: Davies (2010).

22 The book was published in two languages: Castilian and Galician. See: http://www.casadellibro.com/librogalicia-unha-luz-en-el-atlantico/9788483027189/806181 (1.09.2012) 


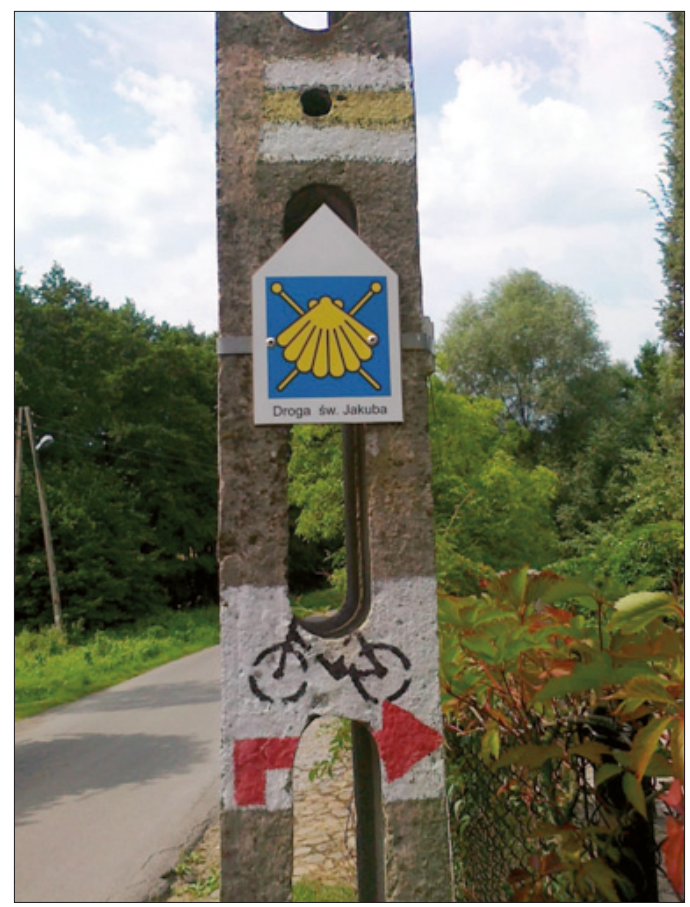

Photo 1. The sign of Camino de Santiago (St. James's Way) in Lednica Górna.

(All photographs by Karolina Golemo.)

What shall be done in order to overcome this ignorance [literally descoñecemento - lack of knowledge] about us which we face and which in the era of globalization and open frontiers becomes an even bigger problem since what is unknown is difficult to be judged, loved or, simply, taken into consideration. When twenty years ago I visited for the first time the Frankfurt International Book Fair, I had to explain to my European colleagues where Galicia was located so that they did not confuse it for example with the Polish-Ukrainian Galicia, Chopin and Pope Wojtyła one and ended up having to mention the St James's Way (Freixanes, 2008).

The author further recalls that it was only after making a reference to St James's Way (which he himself calls a 'religious, symbolic and cultural fact') that his interlocutors managed to locate the Spanish Galicia in the right place on Europe's map.

Included in the Unesco World Heritage List since 1993, St. James's Way (which exists since the $9^{\text {th }}$ century) is doubtless the most easily recognizable symbol of the Spanish Galicia not only in the pilgrim's environment. It offers a gateway from the daily routine, a chance to enjoy unique landscapes of the Spanish soil, eagerly chosen by tourist from Europe and the rest of the world. Although peace and quiet and contemplation are rather hard to find there, considering an immense popularity of these routes, experiences gained during this journey unlike any other may be unforgettable. Spanish regions tend to be so charming that the desire to be close to and absorb the surroundings may end up obscuring the main goal of the trip, i.e. arriving at the Santiago's Cathedral. It was the case, for instance, of the ethnographer Jacek Kukuczka, a Custodian of the Ethnographic Museum in Cracow, who from 2004 has travelled across the numerous routes 
leading to the same destination throughout different Spanish regions, but who has never yet reached the goal. 'Maybe one day I will manage' - he confessed during a presentation of his pictures and travel memoires. ${ }^{23}$ Santiago de Compostela's symbol is a regularshaped shell which resembles to a fan (known in Spain under the Galician name vieira), characteristic to the Galician sea shore. Pilgrims who visit St James The Greater's tomb used to take these shells from the ocean on their way back home as a proof that they reached the destination. In Christian iconography a shell constitutes St. James's attribute. A legend has that the Apostle gave water to a thirsty pilgrim in a huge shell (Łempicka \& Łempicki, n.d.). These original vieiras which mark the pilgrim routes since the Middle Ages can be found also in Malopolska. The Santiago's shell, ${ }^{24}$ referred to as 'przegrzebek śródziemnomorski' (Corbeil \& Archambault, 2007, p. 157) in Poland, may be found for instance in the village of Lednica Górna, close to the town of Wieliczka (see Photo 1). This blue and yellow sign painted on a transmission pole which points the way to Santiago de Compostela may be considered as yet another symbolic link between the two Galicias the Atlantic and the central European.

St. James's Way symbol is an element of the landscape also in many other locations of the Polish Galicia. Malopolska used to be the area where a former trade route lead from Rus to Spain, known in Poland as the so-called Wysoka Droga (High Route) or Royal Route (Via Regia). Along the route lied places, where pilgrims could ask for care and assistance: shelters, hospitals and churches dedicated to St James the Apostle, patron of the pilgrims. ${ }^{25}$ With time the High Route started functioning as a pilgrim route to Santiago. On Małopolska Cultural Institute's website, in the section 'Małopolska's routes' we find an article dedicated to St. James' Way in Małopolska. ${ }^{26}$ Within the Polish Galicia's area we can actually distinguish two routes which form part of the European net called Camino. The first one coincides with the Via Regia trade route, which links the East with the West of Europe. ${ }^{27}$ The second is a $192 \mathrm{~km}$-long tract created in 2007 land opened a year later) called Malopolska's via crucis of St. James. It leads from Sandomierz to Cracow, via, among other localities, Pińczów, Skalbmierz, Pałecznica and Więcławice Stare.28 In small villages scattered along this route there are a dozen of churches dedicated to St. James the Greater. According to medievalists, their presence may indicate that a pilgrim route to Santiago de Compostela existed in Malopolska in the Middle Ages and these buildings may have been functioning as Station Churches. Their proximity allowed pil-

23 Jacek Kukuczka shared his experiences during lectures organised by Krakowski Oddział Polskiego Towarzystwa Ludoznawczego (Cracow Branch of the Folkloristic Society) at the Ethnographic Museum in Cracow on 13 February 2012. The presentation was entitled 'Etnograf na camino. Obserwacja z dróg do Santiago de Compostela', (trans. Ethnographer on camino. Observations from routes to Santiago de Compostela', http:// etnomuzeum.eu/index.php?action=Aktualnosci,371_zapraszamy_na_spotkanie_ptl (1.09.2012).

24 In French this type of shell is known until today under the name Coquille Saint-Jacques, i.e. St. James's shell'. In mediaeval France this symbol was related to pilgrimage in general and used not only by pilgrims coming back from Santiago de Compostela, but also from Le Mont-Saint-Michel or the Holly Land. See "Coquille et Compostelle" (n.d.).

25 These buildings are currently located in Brzesko, Tuchów, Sławków, Jarosław, Cracow's Kazimierz and Sandomierz. In the Middle Ages St. James the Apostle was worshiped as a patron of the fight against the Moors on the Iberian Peninsula and subsequently as a patron of knights, pilgrims and travelers.

26 St. James' Way in Małopolska. The text was prepared by Stowarzyszenie Przyjaciele Dróg św. Jakuba w Polsce (2013, Association of St. James's Ways in Poland).

27 St. James's Way (Via Regia) is marked out at present by the following points: Przemyśl - Rzeszów - Tarnów - Kraków - Olkusz - Piekary Śląskie - Opole - Wrocław - Legnica - Zgorzelec. As quoted: Stowarzyszenie Przyjaciele Dróg św. Jakuba w Polsce (2013).

28 On the website of Malopolska's St. James's Way: „It encompasses the area of the historis Piast country (Cracow's and Sandomierz's provinces) and related to the mediaeval route which lead along the edge of the Vistula valley from Sandomierz to Cracow. This tract constituted one of the branches of the so-called Rus route which lead from Polesie and Rus to the Crown's capital and to Silesia' ("Małopolska Droga św. Jakuba", n.d.). 
Photo 2. Santiago shell upon a river in the Ojców National Park.
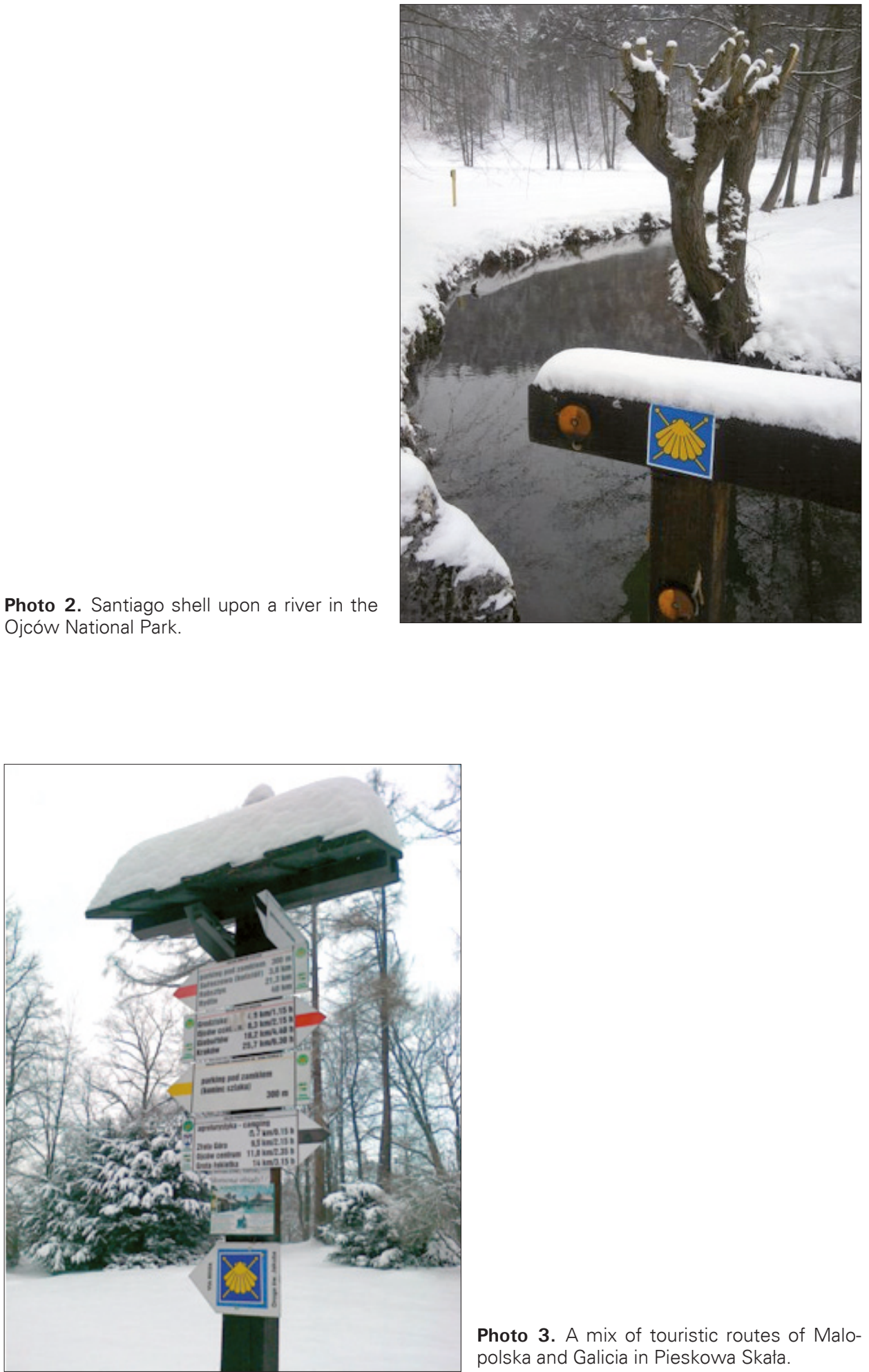

Photo 3. A mix of touristic routes of Malopolska and Galicia in Pieskowa Skała. 
grims to cover subsequent stages of the route within one day. ${ }^{29}$ Yellow and blue signs representing shells which ornament Malopolska look particularly enchanting in winter: on the snowy rocks, ice-bound river in Ojcowski Park Narodowy (Ojców National Park) or contrasting with the whiteness of the snow banks near the castle at Pieskowa Skata. In forests and country lanes, where smooth surfaces on which to stick or paint a sign are hard to find, an alternative sign known also in Spain is adopted, that of a yellow arrow (Zawadzki, 2013).

Going back to the Spanish Galicia: some Galicians fight to have their region treated as a whole, without it being identified only with Santiago. Others see this issue in a completely different way: they want to promote the city with St James's tomb as an emblem of this part of Spain and refrain from references to the Galicia itself to avoid it being confused with the 'other Galicia' in Poland. José Antonio Linares, member of Santiago de Compostela Hoteliers Association, ${ }^{30}$ thinks that regional authorities should promote first of all St James's Way because it is this route, and not the remaining part of Galicia, that belongs to the 'tourist must see places' of the area (Montero, 2009). La voz de Galicia of 15 th December 2010 published an insert entitled Economía Santiago, with a series of reports and articles showing the contribution of St James's Way to the development of the region and how the route helped to mitigate the effects of the 2010 crisis. It is enough to look at the newspapers' titles and subtitles: 'Compostela trade mark sells', Santiago's trade mark works', 'Santiago climbes on the economic podium' (behind A Coruña and Vigo), 'St. James's Way becomes a luxurious economic powerhouse', 'Compostela reaches foreign markets', etc. (Montero, 2009). In fact, in the case of such well promoted and catching trademark (Santiago de Compostela), which works on a pars pro toto basis for the entire Spanish Galicia, why risk promoting the name of a region which is often mistaken with another one, located in the central Eastern Europe?

It looks like mistaking the Atlantic Galicia with the Polish one irritates also the Galician nationalists. During a campaign for the European Parliament elections in 2008 there was an information in one of the articles that a leftist formation Bloque Nacionalista Galego, BNG, demands that the region of Galicia become more widely represented in Europe (Gago, 2009), mainly in terms of allocation of European funds, in which the Galician MPs had too little a say so far, according to the nationalists. The European Parliament candidates from BNG had set themselves clear goals: make Galicians' voice heard, protect local manufacturing, ensure a better redistribution of the European funds and make the galego language one of the official languages of the European Union. According to the BNG's spokesman Guillerme Vázquez, 'Galicia is a European country with a European language' and, as such, needs to be more visible in Europe, also so that other countries' MPs learn about the existence of this Galicia (in original Galiza - the name of the Spanish region in the galego language, championed by the nationalists - K. G.), and not only the Polish Galicia (Gago, 2009) ${ }^{31}$.

The fact that so distant regions joined by the same name may be confused is confirmed also by one media incident. A TVG television journalist Xosé Durán, when remembering the beginnings of his co-operation with a Galician editor, told an anecdote about

29 See "Małopolska Droga św. Jakuba" (n.d.).

30 See the website of the Association: http://www.santiagohosteleria.net/es/contacto/contacto.asp (3.09.2012).

31 By way of explanation: the Spanish region in Spanish (Castilian) is named Galicia, while in galego a different name, Galiza, is often used (according to some researchers the latter is promoted by Galician nationalists and separatists). To differentiate Polish Galicia is called Galitzia. The intricacies are described by, among others, Blanco Valdés (2005). 
a funny misunderstanding which linked the two distant Galicias. He gave his memoires a meaningful title: 'Is Galicia located in Poland?' Durán recalls that the first international sport transmission to be broadcast by the Galician TVG was supposed to be a well publicised football match between Young Boys from Switzerland and Real Madrid. On the due date a TVG technician asked his colleagues in London responsible for the satellite transmission to send the transmission signal to Galicia. English technicians assured to have done it, but the viewers gathered in front of their televisions in Santiago could not see anything. Frustrated football fans were trying in vain to change the inclination angle of their satellite dishes. TVG, after a wave of telephone calls from outraged football fans, intervened again by calling the London colleagues and asking for a fine tuning of the signal. It turned out that the signal was transmitted somewhere else. 'They sent it to Galicia, but the Polish one, the historic region which does not exist any longer'. Once the signal was re-transmitted to the correct location the match was about to finish within 15 minutes (Durán, 2012). Anyhow, it was difficult to explain to the viewers that the incident was not to blame on the Galician transmitter, but on the unfortunate name coincidence. At least foreign teams responsible for transmission of the satellite signal had no doubt where to send it from then onwards. Finally everyone knew that 'there is Television de Galicia at the Atlantic shores' (Durán, 2012).

\section{GALICIAN PARTNERSHIP ON SOLID FOUNDATIONS OF (IMAGINED) SIMILARITY}

Since the names of the two regions are so akin, it is tempting to find some other common traits. Part of them was half-jokingly described by the journalists quoted earlier in this article. One of them went even further in his research to discover Zabierzów, a locality near Kraków. He showed that 'if we were to cut the initial ' $Z a$ ' and the last ' $w$ ' in the Polish town's name, it would change in Bierzo. ${ }^{32}$ On the date of Poland's accession to the European Union a Galician journalist from 'La voz de Galicia' wrote: 'Similarly to Ural on the north-east, on the south-west Galicia is the land's end for each Pole (sic!). But at the end we have something in common. The author sarcastically jokes that Polish Galicia resembles the Spanish one 'from the times before the sanitary checks of cows were introduced'. And he further writes that Spanish and Polish Galicians [galitzianos y galicianos] are united by 'cows breeding and tractors popularisation', and also by the fact of being a poor region among the rich ones' (Blanco, 2004).

Symbolic parallels aside, real palpable premises for similarities do exist. In other words, the feeling of closeness, independently of how much of it is imagined and 'forced' by the name coincidence, may sometimes turn into something real'. Over a decade ago the cultural partnership was sealed between the 'sister' towns of the two Galicias: Cracow and Lugo. Polish (to be more precise Krakow's and Galician) culture and art was presented in the Atlantic city. The then-Polish ambassador of Spain expressed an opinion, brought about in the article La voz de Galicia, that the fraternisation of the two regions will cause that 'Galicia will know the Galicians from Poland' [los Gallegos de Polonia] and vice versa, that the inhabitants of the Polish Galicia will get to know better the other one,

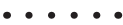

32 Bierzo is a comarca, i.e. a small administrative unit in the region of Castilla y León, whose inhabitants use galego language as well due to its proximity to Galicia. Perhaps because of this the author included this remark in the text related to the existence of two Galicias. See Cuenya (2005). 
because so far they associated it only with Santiago de Compostela ("Lugo conoce a la Galitzia polaca", 2000). Considering that the article presented Cracow (whose old town is among 'the most beautiful old towns in the world' - without specifying which ones) as a city which lies between The Carpathians and the Baltic Sea, on the left bank of the upper Vistula' we can not argue with the author that Spain needs more information about 'the other Galicia' ("Lugo conoce a la Galitzia polaca", 2000).

Other more concrete examples of symbolic relationship is the presentation of exhibits from Kraków's museums organized every few years in Santiago de Compostela (Pino, 2004; Gago, 2006) or klezmer music concerts 'From Galicia to Galicia' which take place under the patronage of Galician Association of Friendship with Israel.' ${ }^{33}$ Under the flag of 'Galician solidarity' and the klezmer theme the Krakow band Kroke visited Spanish Galicia with a concert ("Kroke trae ao Auditorio os ritmos xudeus de Galitzia", 2004).

A proof of the existence of a Galician fraternity may be represented by a documentary about the figure of Marcos Gallego, a Galcian, entitled "A outra Galicia" (The other Galicia). A film journey through the area today divided between Poland and Ukraine was, in the author's concept to give a testimony on how the people of the other Galicia lived, show their culture, tradition, economy foundations, society and landscapes... ${ }^{34}$ This documentary made in 2004 became subsequently an inspiration for the film, "A maleta de Sofía" (2011), about the life of Sofia Casanova Lutosławska. ${ }^{35}$ The director said in one of the interviews:

[...] I had good memories from September 2004, when during a visit in the south-eastern Poland, the Polish Galicia, I was shooting a documentary The other Galicia. Sometimes I almost forgot that I was in Poland, so similar it was from the toponymic, landscape and anthropologic (gastronomy, folklore, etc.) point of view to the Spanish Galicia where I was born'. ${ }^{36}$

Intrigued by the director's statement, I decided to enquire about these similarities between the distant European regions. Marcos Gallego eagerly shared his impressions with me. What did the two Galicias have in common, according to him? Narrow streets criss-crossing tree alleys, soft hills, sheep and cows grazing on green pastures and crystal clear rivers. To this idyllic, bucolic landscape the director adds farmers who transport their tools and food for the animals on horse-pulled cars. Polish Galicia resembled his native land also because of the sympathy and warmth of its inhabitants, 'gastronomic abundance', autumn colours and forest scent ${ }^{37}$. Memoirs dating back almost a decade indicate a similarity between the two Galicias first and foremost in the rural culture domain (Europe's farming 'museum' with a still uncontaminated nature) and traditional bucolic stylistics. ${ }^{38}$

\footnotetext{
-....

33 See Asociación Galega de Amizade con Israel (2008).

34 Information from the website of Axencia Audiovisual Galega (n.d.).

35 See Stowarzyszenie Dziennikarzy Polskich (2011).

36 See Truszczyński \& Gallego (n.d.).

37 From a private e-mail correspondence with Marcos Gallego (October 2012).
}

38 In the book Antropologia cultural de Galicia (Cultural antropology of Galicia) Carmelo Lisón Tolosana describes customs and traditions of Galicia's rural society, which to a great extent survived until modern times. With a great understanding for th Galicians mentality and at the same time a dose of humour, the author shows how important a part cow plays in Galicians lives: they not only live 'thanks to it', but in many cases 'for it'. There are countless magical-religious rituals related to cows, for instance rituals which accompany its first entrance to the cowshed or those protecting it from the evil eye (Spanish mal de ojo, Galician mal de ollo) of an envious neighbour. See Tolosana (1979, pp. 27-29). Spanish Galicia's emblem, a cow which was saved from flood along with its two ownes (Galician peasants) features as one of the main 'characters' in the film Crebinsky (directed by E. Otero, 2011), presented in Cracow during the $13^{\text {th }}$ Week of the Spanish Film in Cracow. 
An interesting area for comparisons of the two regions is their cuisine and nutritional habits. A good starting point for gastronomic analyses may be our popular 3-component dish: fried pork in bread crumbs, potatoes and cabbage in juxtaposition with the food trends in the Atlantic Galicia. Both regions have undoubtedly in common the love of pork dishes in any possible form. Spanish Galicians' culinary repertoire comprises, for instance, pork ears and mouth (Gal. orellas e morros de porco) served in salt and pepper. They also like their own version of tripe made of pork stomach (Gal. callos de porco). Other pork delicacies are lacón or zorza ${ }^{39}$. Baked potatoes, called cachelos, are also popular, in many varieties and forms. Similarly like in our Galicia, young potatoes, named patacas novas, are eagerly consumed. The last element of the 3 components mentioned earlier, i.e. the cabbage is in turn a main ingredient of a Galician soup: o caldo galego. Apart from normal cabbage (Gal. repolo) and the Savoy cabbage (Gal. la verza), the flavours of the Galician soup are enhanced by Rutabaga levaes (Gal. grelo), potatoes, lard and usually a meat component. We could go further with these culinary comparisons between the two Galicias, considering popular 'firewaters' (Gal. aguardentes) and our Polish distilled beverages.

The question on what links the two Galicias is asked by Spanish Internet surfers as well. Some try to carry out in-depth linguistic and historic analyses, other simply summarise the problem in few words: 'I am a Galician. Believe me, there is no connection but for the cold and rain. '40 A comment on one of the portals read: 'I was amused when a Polish friend of mine asked me why the Catalan people are called 'Poles'. By the way, he informed me that his region's name is 'Galicia'. Are they [people from Polish Galicia] called 'Spaniards?'41 As we can see the issue is pretty intriguing and it would probably be difficult to find a satisfactory solution.

Both Galicias are unquestionably linked by the love for all sorts of diminutives. People from Krakow treat diminutives as the most natural thing and see them as an expression of kindness towards clients or interlocutors while to the outsiders this manner may be irritating. We therefore pay with 'pieniążki' and receive 'rachuneczek'42 ('pieniądze' and 'rachunek' sound too coarse for us). Counterparties, in order not to offend us, issue us with 'fakturki', we go the bakery to buy fresh 'chlebuś' and a shop assistant asks us politely whether to put it in a 'torebeczka'. Even at a surgery I heard once that 'wyniczek (result of some analysis) will be available tomorrow. It so happens that diminutives are also an important feature of the communication culture of the Spanish Galicians. When a Galician farmer says 'my little car', 'my little house' (meu carriño, miña casiña), it does not mean, as explained by the authors of the Spanish encyclopaedia's dictionary, that they intend a car small in dimension or an unusually small-sized house. It is about a particular emotional attitude, almost as if he was talking: 'my dear car, which helps me in my daily efforts', 'my sweet home, which brings me rest'. This characteristic inclination of the Galician language towards diminutives, according to the authors, proves its extraordinary richness and elasticity'. ${ }^{43}$ Therefore a saying 'quérote moitiño' does not mean other in Galician than an expression of a great feeling, which is not diminished in his force by

\section{$\cdots \cdots$}

39 Recipees for those and other Galician pork specials (Spanish: costilla de cerdo guisada con patatas, chorizos gallegos, churrasco de cerdo, lacón asado al horno, lomo de cerdo con salsa de queso azúl, pastelitos de lacón itp.) may be found on the website: http://www.lacocinadelechuza.com/2008/01/zorza-con-patatas. html (10.09.2012).

40 http://es.answers.yahoo.com/question/index?qid=20100828194804AAmsSi4 (10.09.2012).

41 http://rinzewind.org/archives/2006/11/15/la-europa-de-los-estados (10.09.2012).

42 All the Polish terms given in this paragraph are examples of diminutives which are difficult to be translated to English.

43 See Dicionario de Dicionarios (n.d.). 
the diminutive. Both Galicias can boast as well a higher degree of linguistic complexity when it comes to diminutives of diminutives (ultra-diminutivos): dog-doggie-little doggy (Pol. pies - piesek - pieseczek (can - cadelo - cadeliño), panienka, panieneczka (señorita - señoritiña)...

Lastly, we could ask a question whether the two Galicias have in common any 'national characteristics'? Whether Galician melancholy, hesitancy and chronic moriña are somehow linked to our sentimentalism, romanticism, constant nagging and tendency to martyrology? Or maybe the entrepreneurship of the Krakow people and prudence in spending, often called 'centusiowanie' (cents counting), have something in common with Galician conservatism and caution? (Czuma \& Mazan, 1998, p. 67). Do Galician women known for their independence and courage have anything in common with an average Matka-Polka (Matka-Galicjanka ${ }^{44}$ ) ${ }^{45}$ These issues could be subject of long discussions on stereotypes between the Spanish and Polish Galicians, possibly to the sounds of characteristic melodies played on gaitas, which in Poland are known as 'gajdy'.

\section{BIBLIOGRAPHY}

"Mis niños tienen aquí una calidad de vida maravillosa". (2007, May 23). La Voz de Galicia. Retrieved September 6, 2012, from http://www.lavozdegalicia.es/hemerote$\mathrm{ca} / 2007 / 05 / 23 / 5833006 . s h t m l$

Alcalá, X. (2006, June 14). De agora ao AVE. La Voz de Galicia. Retrieved September 3, 2012, from http://www.lavozdegalicia.es/hemeroteca/2006/06/14/4860495.shtml

Antón, B, (2008, May 7). Una pianista de Céltigos que gana premios en Cracovia. La Voz de Galicia. Retrieved September 6, 2012, from http://www.lavozdegalicia.es/ferrol/2008/05/07/0003_6797084.htm

Asociación Galega de Amizade con Israel. (2008). Desde Galitzia a Galicia: A música klezmer patrimonio cultural de Europa. Retrieved September 10, 2012, from http://agaigalicia-israel.blogspot.com/2008/04/desde-galitzia-galicia-msica-klezmer.html

Axencia Audiovisual Galega. (n.d.). Retrieved September 10, 2012, from http://www. axenciaaudiovisualgalega.org/public/index.php?id_proyecto=322\&seccion=oficinaprod uccion/ficha_proyecto.php

Barreiro Rivas, X.L. (2005, February 17). ¡Viva la pobreza! La Voz de Galicia. Retrieved September 10, 2012, from http://www.lavozdegalicia.es/hemeroteca/2005/02/16/3470064. shtml

Blanco Valdés, R. N. (2005, September 24). Galiza no existe. La Voz de Galicia. Retrieved September 3, 2012, from http://www.lavozdegalicia.es/hemeroteca/2005/09/24/ 4100610.shtml?utm_source=buscavoz\&utm_medium=buscavoz

Blanco, L. (2004, May 1). ¡A apretarse los machos! La Voz de Galicia. Retrieved September 10, 2012, from http://www.lavozdegalicia.es/hemeroteca/2004/05/01/2641126. shtml?utm_source=buscavoz\&utm_medium=buscavoz

44 Literally Polish Mother; Galician Mother. On the stereotype of Polish women see Malgorzata Fidelis (2010, pp. 24-25).

45 On the strength and particular social position of the Spanish Galician women see Poska (2006). On matrilineal kinship system in Galicia, its origins and consequences see Tolosana, (1979, Chapter. VIII: "Manda matrilineal", pp. 243-272. 
Bugallal, I. (2008). Gosia Trebacz: "Compraba libros de pintura y me miraban fatal, claro". Retrieved September 6, 2012, from http://www.laopinioncoruna.es/secciones/noticia. jsp?pRef=2008043000_16_186238__Contraportada-Gosia-Trebacz-Compraba-librospintura-miraban-fatal-claro

Casal, C. (2012, June 7). Philip Roth, de Galitzia a Asturias. La Voz de Galicia. Retrieved September 1, 2012, from http://www.lavozdegalicia.es/noticia/opinion/2012/06/07/philip-roth-galitzia-asturias/0003_201206G7P19994.htm

Coquille et Compostelle. (n.d.). Retrieved July 15, 2013, from http://www.saint-jacques. info/coquille.html

Corbeil, J.-C., \& Archambault, A. (2007). Stownik obrazkowy polski-hiszpański: 20000 haset. Poznań: Wydawnictwo LektorKlett.

Cuenya, M. (2005, October 10). Cracovia, Galicia y El Bierzo. Diario del León. Retrieved September 10, 2012, from http://www.diariodeleon.es/noticias/bierzo/cracovia-galiciay-bierzo_221637.html

Cultura Galega. (n.d.) Retrieved September 6, 2012, from http://www.culturagalega.info/ datodirectorio/asociacion-de-pianistas-galitzia

Czuma, M., \& Mazan, L. (1998). Austriackie gadanie, czyli encyklopedia galicyjska. Kraków: Oficyna Wydawniczo-Handlowa Anabasis

Davies, N. (2010). Boże igrzysko: Historia Polski. (E. Tabakowska, Trans.). Kraków: Znak.

Dicionario de Dicionarios. Corpus lexicográfico da lingua galega. (n.d.). Retrieved January 15, 2013, from http://sli.uvigo.es/ddd/ddd_pescuda.php?pescuda=diminutivo\&tipo_ busca=lema

Dopico, M. (2011, July 9). ¿Quién conoce a Sofía Casanova? El Mundo. Retrieved September 10, 2012, from http://www.elmundo.es/elmundo/2011/07/09/galicia/1310206393. html

Durán, X. (2012). Galicia está en Polonia? Arquivo CRTVG (Compañía de Radio-Televisión de Galicia). Retrieved September 5, 2012, from http://www.crtvg.es/crtvg/arquivo/galicia-esta-en-polonia

Europa y el "mito de la Galicia verde". (2006, June 2). La Voz de Galicia. Retrieved September 3, 2012, from http://www.lavozdegalicia.es/hemeroteca/2006/06/02/4827030. shtml?utm_source=buscavoz\&utm_medium=buscavoz

Fidelis, M. (2010). Women, communism, and industrialization in postwar Poland. Cambridge: Cambridge University.

Filipowicz-Rudek, M. (2012). Ta druga Galicja. Studia Iberystyczne, 2. (Almanach Galicyjski, 1).

Filipowicz-Rudek, M. (2003). Más que amor: Sofía Casanova Lutosławska, princesa de las nieves polacas. Estudios Hispánicos, 11, 165-171.

Freixanes, V. F. (2008, September 28). O caso Steiner. La Voz de Galicia. Retrieved September 3, 2012, from http://www.lavozdegalicia.es/opinion/2008/09/28/0003_7178105. htm

Freixanes, V. F. (Ed.). (2001). Galicia: Unha luz en el Atlántico. Vigo: Xerais.

Gago, X. V. (2006, March 24). La pequeña Polonia muestra sus atractivos en Compostela. La Voz de Galicia. Retrieved September 10, 2012, from http://poloniaengalicia.com/ prensa/2005y2006/2006-03-24-VG-Polonia-muestra-atractivos.pdf

Gago, X. V. (2009, May 23). El BNG quiere voz en el reparto de fondos de la UE y acabar con los eurodiputados gallegos "caladiños». La Voz de Galicia. Retrieved Septem- 
ber 3, 2012, from http://www.lavozdegalicia.es/espana/2009/05/23/0003_7736289. htm?utm_source=buscavoz\&utm_medium =buscavoz

Galicia duplicó el último año sus exportaciones a Polonia. (2002, March 30). La Voz de Galicia. Retrieved September 10, 2012, from http://www.lavozdegalicia.es/hemeroteca/2002/03/30/1026367.shtml?utm_source=buscavoz\&utm_medium=buscavoz

Hooper, K. (2008). A stranger in my own land: Sofía Casanova, a Spanish writer in the European fin de siècle. Nashville: Vanderbilt University Press

Hooper, K. (2010). Sofía Casanova e o apagamento da muller intelectual no seculo XX español. In A. M. Pazos (Ed.), Vida e tempo de Sofía Casanova (1961-1958). Santiago de Compostela: Editorial CSIC.

Kroke trae ao Auditorio os ritmos xudeus de Galitzia. (2004, November 19). La Voz de Galicia. Retrieved September 10, 2012, from http://www.lavozdegalicia.es/hemerote$\mathrm{ca} / 2004 / 11 / 19 / 3222126 . s h t m l$ ?idioma=galego [the link has expired]

La "Galicia" más pobre del continente llama a las puertas de la Unión Europea. (2002, March 28). La Voz de Galicia. Retrieved September 10, 2012, from http://www.lavozdegalicia.es/hemeroteca/2002/03/28/1025868.shtml?utm_source=buscavoz\&utm_ medium =buscavoz

Lewandowski, E. (2005). Pejzaż etniczny Europy. Warszawa: Muza.

Loureiro, R. (2005, April 2). Los obispos recuerdan conmovidos el afecto de Juan Pablo II por Galicia. La Voz de Galicia. Retrieved September 3, 2012, from http://www.lavozdegalicia.es/hemeroteca/2005/04/02/3599418.shtml?utm_source=buscavoz\&utm_ medium =buscavoz

Lugo conoce a la Galitzia polaca. (2000, November 3). La Voz de Galicia. Retrieved September 10, 2012, from http://www.lavozdegalicia.es/hemeroteca/2000/11/03/271232. shtml

Łempicka, M., \& Łempicki, J. (n.d.). Święci w Polsce i ich kult w świetle historii. Retrieved September 11, 2012, from http://sancti-in-polonia.dle.interia.pl/2j.html

Małopolska Droga św. Jakuba. (n.d.). Retrieved July 12, 2013, from http://www.malopolskadroga.swjakub.pl

Martínez, M. R. (1999). Sofía Casanova: Mito y literature. Santiago de Compostela: Xunta de Galicia.

Molina, C. A. (2002, January 11). El Santo Bebedor. La Voz de Galicia. Retrieved September 1, 2012, from http://www.lavozdegalicia.es/hemeroteca/2002/01/11/908804.shtml

Montero, T. (2009, December 20). "A marca de Santiago é o canón turístico, moito máis que Galicia". La Voz de Galicia. Retrieved September 3, 2012, from http://www.lavozdegalicia.es/santiago/2009/12/20/0003_8183719.htm

Os cadernos perdidos de Sofía Casanova. (2011, June 26). El Correo Gallego. Retrieved September 9, 2012, from http://www.elcorreogallego.es/indexSuplementos. php?idMenu=17\&idNoticia $=682157$

Piñeiro, A. (2010, September 24). "A música galega de hoxe é mais plural que a de hai unha década ". La Voz de Galicia. Retrieved June 9, 2012, from http://www.lavozdegalicia.es/barbanza/2010/09/24/0003_8743218.htm

Pino, C. (2004, April 15). Galitza en Galicia, dous recantos. La Voz de Galicia.

Pogoriles, E. (2012, October 21). Galicia y su doble. Retrieved October 24, 2012, from http://www.clarin.com/viajes/Galicia-doble_0_796120412.html

Poska, A. M. (2006). Women and authority in early modern Spain: The peasants of Galicia. Oxford: Oxford University Press. 
Premio de príncipes para Renacer. (2011, December 2). La Voz de Galicia. Retrieved September 3, 2012, from http://www.lavozdegalicia.es/coruna/2011/12/02/0003_201112H 2C5994.htm?utm_source=buscavoz\&utm_medium=buscavoz

Ramírez, C. (2002, March 17). "No utilizamos 'nacionalismo' porque es una palabra excluyente para algunos". La Voz de Galicia. Retrieved September 1, 2012, from http://www.lavozdegalicia.es/hemeroteca/2002/03/17/1010162.shtml?utm_source= buscavoz\&utm_medium=buscavoz

Ramonet, I. (2002, November 26). Guerra ecológica. La Voz de Galicia. Retrieved September 1, 2012, from http://www.lavozdegalicia.es/hemeroteca/2002/11/26/1338926. shtml

Sampedro, D. (2002a, March 28). Formados, pero sin empleo. La Voz de Galicia. Retrieved September 10, 2012, from http://www.lavozdegalicia.es/hemeroteca/2002/03/28/1025873.shtml?utm_source=buscavoz\&utm_medium=buscavoz

Sampedro, D. (2002b, March 31). Los ganaderos del sur de Polonia venden la leche $20 \%$ más barata que los gallegos. La Voz de Galicia. Retrieved September 10, 2012, from http://www.lavozdegalicia.es/hemeroteca/2002/03/30/1026637.shtml?utm_source= buscavoz\&utm_medium=buscavoz

Sampedro, D. (2004, November 27). Una llave polaca para los fondos estructurales. La Voz de Galicia. Retrieved September 3, 2012, from http://www.lavozdegalicia.es/hemeroteca/2004/11/27/3246021.shtml

Stowarzyszenie Dziennikarzy Polskich. (2011, September 8). Walizka Sofii. Retrieved September 10, 2012, from http://www.sdp.pl/sofia-casanova-lutoslawska

Stowarzyszenie Przyjaciele Dróg św. Jakuba w Polsce. (2013). Droga św. Jakuba w Matopolsce. Szlaki Małopolski. Retrieved July, 10, 2013, from http://szlakimalopolski.mik. krakow.pl/?szlaki=wejdz-na-szlak-droga-sw-jakuba-w-malopolsce

Szostak, V. (2011, January 12). Przypadki Sofii Casanovy. Wysokie Obcasy. Retrieved September 7, 2012, from http://www.wysokieobcasy.pl/wysokie-obcasy/1,100958,89 08052,Przypadki_Sofii_Casanovy.html?as=4\&startsz=x\&startsz=x\&startsz=x

Tolosana, C. L. (1979). Antropologia cultural de Galicia. Madrid: Akal Editor.

Truszczyński, S., \& Gallego, M. (n.d.). Rozmowa z hiszpańskim reżyserem Marcosem Gallego o jego filmie o polskiej dziennikarce Sofii Casanova-Lutosławskiej. Stowarzyszenie Dziennikarzy Polskich. Retrieved September 7, 2012, from http://old.sdp.pl/rozmowamarcos-gallego-o-sofii-casanova-lutoslawskiej

Una tierra borrada del mapa que ha perdido hasta su antiguo nombre. (2002, March 28). La Voz de Galicia.

Unha enorme rexión que perdeu o seu nombre. (2004, April 15). La Voz de Galicia. Zawadzki, T. (2013, July 20-21). Wyprawa Drogą św. Jakuba. Polska. Gazeta Krakowska. 